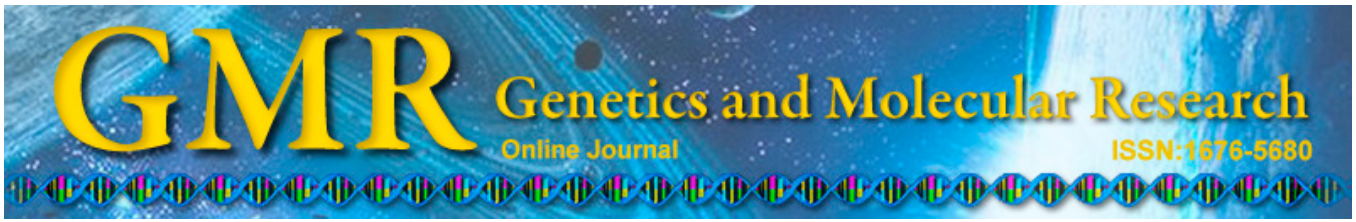

\title{
Genetic diversity and differentiation in Prunus species (Rosaceae) using chloroplast and mitochondrial DNA CAPS markers
}

\author{
S. Ben Mustapha, H. Ben Tamarzizt, G. Baraket, D. Abdallah and \\ A. Salhi Hannachi
}

Laboratoire de Génétique Moléculaire, Immunologie \& Biotechnologie, Faculté des Sciences de Tunis, Université Tunis El Manar, Campus Universitaire, El Manar Tunis, Tunisie

Corresponding author: A. Salhi Hannachi

E-mail: Amel.SalhiHannachi@fsb.rnu.tn

Genet. Mol. Res. 14 (2): 4177-4188 (2015)

Received May 22, 2014

Accepted November 10, 2014

Published April 27, 2015

DOI http://dx.doi.org/10.4238/2015.April.27.33

\begin{abstract}
Chloroplast (cpDNA) and mitochondrial DNA (mtDNA) were analyzed to establish genetic relationships among Tunisian plum cultivars using the polymerase chain reaction restriction fragment length polymorphism (PCR-RFLP) technique. Two mtDNA regions (nad $1 \mathrm{~b} / \mathrm{c}$ and nad $41 / 2$ ) and a cpDNA region (trnL-trnF) were amplified and digested using restriction enzymes. Seventy and six polymorphic sites were revealed in cpDNA and mtDNA, respectively. As a consequence, cpDNA appears to be more polymorphic than mtDNA. The unweighted pair group method with arithmetic mean (UPGMA) dendrogram showed that accessions were distributed independently of their geographical origin, and introduced and local cultivars appear to be closely related. Both UPGMA and principal component analysis grouped Tunisian plum accessions into similar clusters. The analysis of the pooled sequences allowed the detection of 17 chlorotypes and 12 mitotypes. The unique haplotypes detected for cultivars are valuable for management and preservation of the plum
\end{abstract}


local resources. From this study, PCR-RFLP analysis appears to be a useful approach to detect and identify cytoplasmic variation in plum trees. Our results also provide useful information for the management of genetic resources and to establish a program to improve the genetic resources available for plums.

Key words: cpDNA; mtDNA; PCR-RFLP; Plum; Prunus insititia; Prunus salicina

\section{INTRODUCTION}

The genomes of plant organelles have been explored to study population genetic structure and phylogenetic relationships in plants in order to identify species and populations in breeding and conservation programs. The genomes of cytoplasmic organelles (chloroplasts and mitochondria) can be important in population and phylogenetic studies because of their mutation events. Chloroplast and mitochondrial mutations are used to characterize genotypes, differentiate between populations, and clarify their evolutionary history. Plant mitochondrial DNA (mtDNA) has a very low rate of gene sequence evolution, suggesting a much lower rate of point mutation in plant mtDNA than in chloroplast DNA (cpDNA) (Palmer, 1992). The coding regions of mitochondrial genomes are highly conserved across species and genera. Mitochondrial genomes of angiosperms have large intergenic regions and have expanded through frequent duplications, as well as by incorporating introns and DNA segments from the plastid. These non-coding regions (introns and intergenic spacers) are highly variable due to lack of function conservation in sequence (Hu and Luo, 2006), so they have typically been used in phylogenetic and evolutionary studies (Yamagishi and Terachi, 2003; Robertson et al., 2004). Non-coding regions of cpDNA have been explored under the assumption that these regions should be under less functional constraint than coding regions and should hence provide greater levels of variation for phylogenetic analyses (Bouhadida et al., 2007). The variations detected in cpDNA and mtDNA using the polymerase chain reaction-restriction fragment length polymorphism (PCR-RFLP) technique (Wu et al., 1998; Mohanty et al., 2002) are useful for population genetic studies at both intra- and interspecific levels (Dutech et al., 2000; Fineschi et al., 2000). This method is also known as cleaved amplified polymorphic sequences (Konieczny and Ausubel, 1993) and is a readily accessible laboratory technique that can be used to determine large portions of the chloroplast genome in many individuals in a short time and at a lower cost. This method has been used to analyze phylogenetic relationships of cultivated Prunus species (Panda et al., 2003) and to determine the phylogeography and the population diversity in Prunus spinosa and Prunus avium (Mohanty et al., 2002).

Plums (hexaploid, Prunus domestica L. and diploid Prunus salicina L.) have been cultivated for over 2000 years throughout the world. They have attractive colored fruits, which are consumed in both fresh and processed form. Plums belonging to the subgenus Prunophora are considered to be important for Prunus evolution because they include more than 20 species with abundant variations in their morphology (Okie and Weinberger, 1996). In Tunisia, many plum cultivars exist, including very old ones of unknown origin and not derived from breeding programs. In addition, commercial production is essentially represented by introduced varieties recognized for their fruit quality. As a consequence, the local germplasm is threatened by genetic erosion caused by biotic and abiotic stresses resulting in the disappearance of several 
local cultivars. Nuclear polymorphism has been used to provide insights into Prunus genetic diversity and its structure across Tunisian regions (Ben Tamarzizt et al., 2009).

In the present study, we examined the mtDNA and cpDNA variation revealed by RFLP analysis and the objectives of this study were 2-fold: i) to reveal molecular markers and characterize plum cultivars and ii) to give an insight into the level of genetic diversity, and its distribution, in plums.

\section{MATERIAL AND METHODS}

\section{Plant material}

Thirty-eight Tunisian plum plants were collected from the North of Tunisia (Raf-Raf, Ras Djebel, Souinine, Douar Hamouda, and Ghar El Melh), Cap Bon, and Kairouan (Table 1). They included 22 local cultivars ( $P$. salicina), 7 introduced cultivars ( $P$. salicina), and 8 spontaneous accessions (P. insititia). Eighteen accessions were used to detect polymorphisms in cpDNA and 27 were analyzed to study the diversity of mtDNA.

Table 1. Plum cultivars used in the current study and their localities.

\begin{tabular}{|c|c|c|c|}
\hline & Cultivar name & Code & Locality \\
\hline \multirow[t]{22}{*}{ Local cultivars } & Badri & BAD & Ras Djebel \\
\hline & Awina Safra & AWS & Raf-Raf \\
\hline & Jinha & JIH & Raf-Raf \\
\hline & Ain Kounoulia & ANK & Raf-Raf \\
\hline & Cidre & CID & Raf-Raf \\
\hline & Neb Zarouk & NBZ & Raf-Raf \\
\hline & Hamda & HMD & Raf-Raf \\
\hline & Awina Hamra Badria & $\mathrm{AHB}$ & Raf-Raf \\
\hline & Ain Torkia & ATK & Raf-Raf \\
\hline & Zaghouania & ZGW & Raf-Raf \\
\hline & Ain Tastouria & ANT & Raf-Raf \\
\hline & Miski Kahla & MSK & Raf-Raf \\
\hline & Hamra Badri & HBD & Raf-Raf \\
\hline & Ain Ben Moussa & ABM & Souinine \\
\hline & Awina Arbi Baida & $\mathrm{AAB}$ & Raf-Raf \\
\hline & Miski Hamra & MSH & Kairouan \\
\hline & Awina Safra Morra & ASM & Raf-Raf \\
\hline & Hamra Badri 1 & HMB 1 & Cap Bon \\
\hline & Hamra Badri Tardive & НMBT & Kairouan \\
\hline & Hamra Badri 3 & HMB 3 & Kairouan \\
\hline & Hamra Badri 2 & HMB 2 & Kairouan \\
\hline & Adam Hmam & $\mathrm{ADH}$ & Raf-Raf \\
\hline \multirow[t]{7}{*}{ Introduced cultivars } & Golden Japan 1 & GDJ 1 & Raf-Raf \\
\hline & Golden Japan 2 & GDJ 2 & Cap Bon \\
\hline & Golden Japan 3 & GDJ 3 & Raf-Raf \\
\hline & Santa Rosa 1 & STR 1 & Raf-Raf \\
\hline & Santa Rosa 2 & STR 2 & Cap Bon \\
\hline & Black Golden & BLG & Kairouan \\
\hline & Stanley & STL & Cap Bon \\
\hline \multirow[t]{9}{*}{ Prunus insititia } & Sauvage Raf-Raf & SRR & Ghar El Melh \\
\hline & Chaaraouia & CHR & Douar Hamouda \\
\hline & Zanou 6 & ZAN 6 & Ghar El Melh \\
\hline & Sauvage Djebba 1 & SDJ 1 & Djeba \\
\hline & Sauvage Djebba 2 & SDJ 2 & Djeba \\
\hline & Zanou 1 & ZAN 1 & Douar Hamouda \\
\hline & Zanou 2 & ZAN 2 & Douar Hamouda \\
\hline & Zanou 5 & ZAN 5 & Douar Hamouda \\
\hline & Zanou 7 & ZAN 7 & Douar Hamouda \\
\hline
\end{tabular}




\section{DNA extraction, amplification, and digestion}

Total DNA was isolated from fresh leaves using the protocol described by Bernatzky and Tanksley (1986). The concentration of DNA was estimated using a $0.8 \%$ agarose gel. Amplification of the chloroplast region $\operatorname{trn} \mathrm{L}$ (UAA)- $\operatorname{trn} \mathrm{F}$ (GAA) was achieved using universal primers (a-b) designed by Taberlet et al. (1991). The $\mathrm{nad} 1 \mathrm{~b} / \mathrm{c}$ and $\mathrm{nad} 41 / 2$ mitochondrial regions were amplified using primer pairs described by Demesure et al. (1995). The details of the amplification using the cpDNA primer pair are described by Baraket et al. (2010). The amplification using mtDNA primers was performed in a $25-\mu \mathrm{L}$ reaction mixture consisting of $1 \mu \mathrm{M}$ of each primer, $0.2 \mathrm{mM}$ each of the four dNTPs, $25 \mathrm{mM} \mathrm{MgCl}_{2}$, and $5 \mathrm{U}$ Taq DNA polymerase. The PCR amplifications were carried out in a TC-512 thermal cycler, using an initial cycle of 4 min at $94^{\circ} \mathrm{C}$, followed by 35 cycles of $45 \mathrm{~s}$ at $92^{\circ} \mathrm{C}, 45 \mathrm{~s}$ at $53.5^{\circ} \mathrm{C}$ for $n a d ~ 1 \mathrm{~b} / \mathrm{c}$ and $54.5^{\circ} \mathrm{C}$ for $\mathrm{nad} 41 / 2,3 \mathrm{~min}$ at $72^{\circ} \mathrm{C}$, and a final $10 \mathrm{~min}$ extension at $72^{\circ} \mathrm{C}$.

Amplified products, obtained using cpDNA and mtDNA primers, were digested using the following restriction enzymes: HindIII, HinfI, HaeIII, RsaI, EcoRI, and MseI (Invitrogen) for the $n a d 1 \mathrm{~b} / \mathrm{c}$ intron and TaqI, EcoRI, HinfI, and MseI for the nad 4 1/2 intron. The reaction mixture was incubated overnight at $37^{\circ} \mathrm{C}$ with all enzymes and for $5 \mathrm{~h}$ at $65^{\circ} \mathrm{C}$ with only TaqI. The $t r n \mathrm{~L}-t r n \mathrm{~F}$ region was digested using EcoRI, HaeIII, RsaI, HinfI, UspI, ScaI, DraI, AhaIII, XmnI, SacI, ClaI, and BglII. Restriction fragments were separated on 3\% agarose gels and visualized under ultraviolet light.

\section{Data analysis}

Fragments detected were scored on a presence (1) or absence (0) basis and used to identify different haplotypes. The constructed binary data matrix was computed using the Gendist program (version 3.572c), in the computer package PHYLIP (phylogeny inference package, version 3.5c) (Felsenstein, 1995), producing a genetic distance matrix according to the formula of Nei and Li (1979). The neighbor program within PHYLIP was used to produce a tree-file using the unweighted pair group method with arithmetic mean (UPGMA) algorithm. The dendrogram was drawn using the TreeView software (Felsenstein, 1995), based on the obtained treefile. Principal component analysis (PCA) was also performed using the appropriate programs in XLSTAT-Pro (Version 7.0; 2008). Additionally, a minimum-length spanning tree between haplotypes of Tunisian plums was created using Network v4.6 (Bandelt et al., 1999).

\section{RESULTS}

\section{Chloroplast DNA data}

Using the reported $\operatorname{trn} \mathrm{L}-\operatorname{trn} \mathrm{F}$ primers, the PCR generated banding profiles using templates of total cellular DNA. A single DNA band of approximately $1000 \mathrm{bp}$ was amplified from each Tunisian plum cultivar. From the 11 enzymes used, 10 generated polymorphic patterns. These enzymes resulted in 24 different restriction sites, 17 (70.8\%) of which were polymorphic for the 18 individuals analyzed. The percentage of polymorphism ranged from $0 \%$ for $X m n \mathrm{I}$ to $100 \%$ for the EcoRI, HinfI, ScaI, ClaI, and BglII enzymes. The trnL-trnF/XmnIII combination showed a monomorphic pattern. Five enzymes, HaeIII, HinfI, VspI, ClaI, and BglII, showed 2 polymorphic sites and the restriction enzymes EcoRI, ScaI, DraI, and SacI 
generated one polymorphic site. The highest number of polymorphic sites (3) was observed with the RsaI enzyme (Table 2).

Table 2. Mitochondrial and chloroplast polymorphisms detected in plum cultivars using PCR-RFLP analysis.

\begin{tabular}{|c|c|c|c|}
\hline & Total number of sites & No. of polymorphic sites & Percentage of polymorphic sites \\
\hline \multicolumn{4}{|c|}{ Mitochondrial region $\mathrm{Nad} 1 \mathrm{~b} / \mathrm{c}$} \\
\hline HindIII (A/AGCTT) & 2 & 1 & 50.0 \\
\hline $\operatorname{HinfI}(\mathrm{G} / \mathrm{ANTC})$ & 2 & 1 & 50.0 \\
\hline EcoRI (G/AATTC) & 0 & 0 & 0 \\
\hline MseI (T/TAA) & 2 & 0 & 0 \\
\hline HaeIII (GG/CC) & 5 & 2 & 50.0 \\
\hline$R s a \mathrm{I}(\mathrm{GT} / \mathrm{AC})$ & 2 & 2 & 100.0 \\
\hline Total & 13 & 6 & 46.2 \\
\hline \multicolumn{4}{|l|}{ Mitochondrial region $\mathrm{Nad} 4$ 1/2 } \\
\hline TaqI (G/AATTC) & 3 & 0 & 0 \\
\hline EcoRI (G/AATTC) & 1 & 0 & 0 \\
\hline $\operatorname{HinfI}(\mathrm{G} / \mathrm{ANTC})$ & 3 & 0 & 0 \\
\hline MseI (T/TAA) & 2 & 0 & 0 \\
\hline Total & 9 & 0 & 0 \\
\hline \multicolumn{4}{|l|}{ Chloroplast region $t r n \mathrm{~L}-t r n \mathrm{~F}$} \\
\hline EcoRI (G/AATTC) & 1 & 1 & 100.0 \\
\hline HaeIII (GG/CC) & 3 & 2 & 66.6 \\
\hline$R s a \mathrm{I}(\mathrm{GT} / \mathrm{AC})$ & 5 & 3 & 60.0 \\
\hline $\operatorname{HinfI}(\mathrm{G} / \mathrm{ANTC})$ & 2 & 2 & 100.0 \\
\hline$V s p \mathrm{I}(\mathrm{AT} / \mathrm{TAAT})$ & 3 & 2 & 66.6 \\
\hline ScaI (GAGCT/C) & 2 & 1 & 50.0 \\
\hline DraI (TTT/AAA) & 2 & 1 & 50.0 \\
\hline$X m n \mathrm{I}(\mathrm{CAANN} / \mathrm{NNTTC})$ & 1 & 0 & 0 \\
\hline $\mathrm{SacI}(\mathrm{GAGCT} / \mathrm{C})$ & 1 & 1 & 100.0 \\
\hline ClaI (AT/CGAT) & 2 & 2 & 100.0 \\
\hline$B g l I I(\mathrm{~A} / \mathrm{GATCT})$ & 2 & 2 & 100.0 \\
\hline Total & 24 & 17 & 70.8 \\
\hline
\end{tabular}

\section{Mitochondrial DNA data}

Amplification of the $\mathrm{nad} 1 \mathrm{~b} / \mathrm{c}$ and $\mathrm{nad} 41 / 2$ regions resulted in fragments of approximately 1500 and $2000 \mathrm{bp}$, respectively. The tested enzymes resulted in 22 different restriction sites, $6(27.3 \%)$ of which were polymorphic for the 27 individuals analyzed (Table 2). Of the 10 restriction enzymes, 3 (HindIII, HinfI, and HaeIII) generated polymorphic sites (Table 2). The percentage of polymorphism ranged from 0 to $100 \%$ for the $\mathrm{nad} 1 \mathrm{~b} / \mathrm{c}$ intron and $0 \%$ for each enzyme for the nad 4 1/2 intron (Table 2). Two primer-enzyme combinations (nad 1 $\mathrm{b} / \mathrm{c}-H a e I I I$ and nad $1 \mathrm{~b} / \mathrm{c}-R s a \mathrm{I}$ ) showed two polymorphic sites, while nad $1 \mathrm{~b} / \mathrm{c}-H i n d I I I$ and HinfI presented only one site. No polymorphism was detected in the nad $41 / 2$ region using the enzymes studied and only the nad $1 \mathrm{~b} / \mathrm{c}$ region exhibited diversity $(46.2 \%)$.

\section{Genetic distances and relatedness in plum cultivars}

\section{Chloroplast DNA polymorphism}

The genetic distances estimated between accessions ranged from 0.00 to 0.81 , with an average of 0.32 , demonstrating the presence of large molecular polymorphism within the $t r n \mathrm{~L}$ $\operatorname{trn} \mathrm{F}$ region. The lowest distance was obtained between the Awina Hamra Badria and the Jinha cultivars, suggesting that these cultivars are characterized by the highest similarities. A greater distance was observed between the Ain Kounoulia and the Awina Safra cultivars, reflecting their 
large divergence. The topology of the UPGMA dendrogram shows two main clusters (Figure 1). The first cluster (I) comprises the cultivar Awina Safra and all remaining cultivars are grouped into the second cluster (II), and resolved into subgroups. The first subgroup (II-1) is composed of only Zaghouania, and all the other accessions are dispersed in the second (II-2) subgroup. It is worth noting that subgroup (II-2) contains local (cultivated and spontaneous) and introduced cultivars. The distribution of plums occurs independently of their geographical origin and the introduced and spontaneous accessions do not appear to have diverged from the local varieties. PCA based on the RFLP data (Figure 2) produced similar results to those provided by the cluster analysis. Results of PCA showed that $37.4 \%$ of the total variation was explained by the first two principal components, which accounted for 19.8 and $17.6 \%$ of the observed variation, respectively. The two clusters appeared to be well separated and the introduced cultivars Stanley, Santa Rosa 1, and Golden Japan 1 do not appear to have diverged from the local varieties.

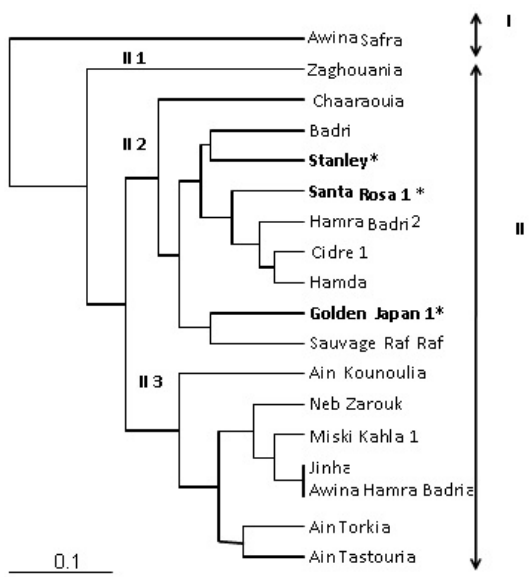

Figure 1. UPGMA dendrogram of 18 plum cultivars based on chloroplast PCR-RFLP markers. Bold *introduced cultivars.

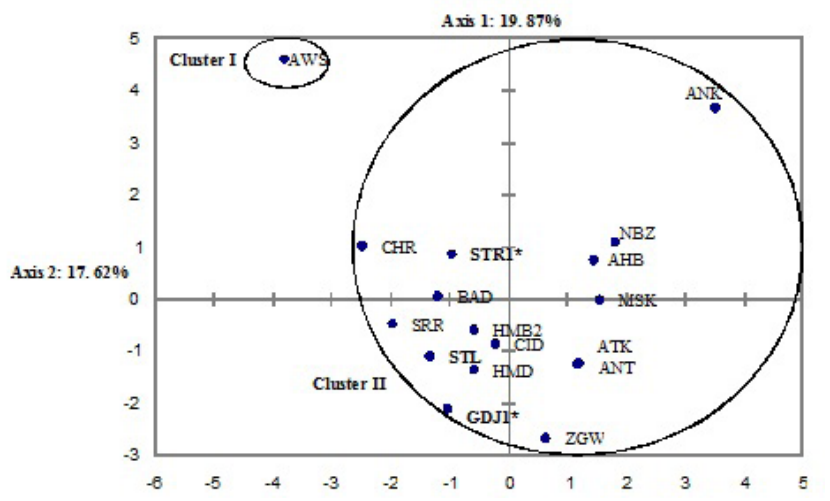

Figure 2. Principal component analysis scatterplot of Tunisian plum cultivars based on chloroplast DNA PCRRFLP markers (37.48\% of the total variability explained). BAD: Badri; AWS: Awina Safra; JIH: Jinha; ANK: Ain Kounoulia; CID: Cidre; NBZ: Neb Zarouk; HMD: Hamda; AHB: Awina Hamra Badria; GDJ1: Golden Japan 1; ATK: Ain Torkia; STR1: Santa Rosa 1; ZGW: Zaghouania; ANT: Ain Tastouria; MSK: Miski Kahla; SRR: Sauvage Raf Raf; HMB2: Hamra Badri 2; STL: Stanley; CHR: Chaaraouia. 


\section{Mitochondrial DNA polymorphism}

The Nei and Li (1979) genetic distances were calculated to elucidate genetic relationships among the 27 plum cultivars analyzed. The distances ranged from 0 to 1 , with a mean value of 0.1 . The constructed UPGMA dendrogram shows two clusters labeled I and II (Figure 3). The first cluster (I) is composed of Miski Hamra and Hamra Badri 1, all the remaining cultivars are clustered in the second group (II). It is important to note that the distribution of cultivars occurs independently of their geographical origin. The multivariate PCA conducted on the mitochondrial data produced a similar result to the one provided by the UPGMA cluster analysis, with $52.7 \%$ of the total variation explained by the first two axes, which accounted for 33.6 and $19.1 \%$ of the variation observed, respectively. The two clusters appeared to be well separated (Figure 4).

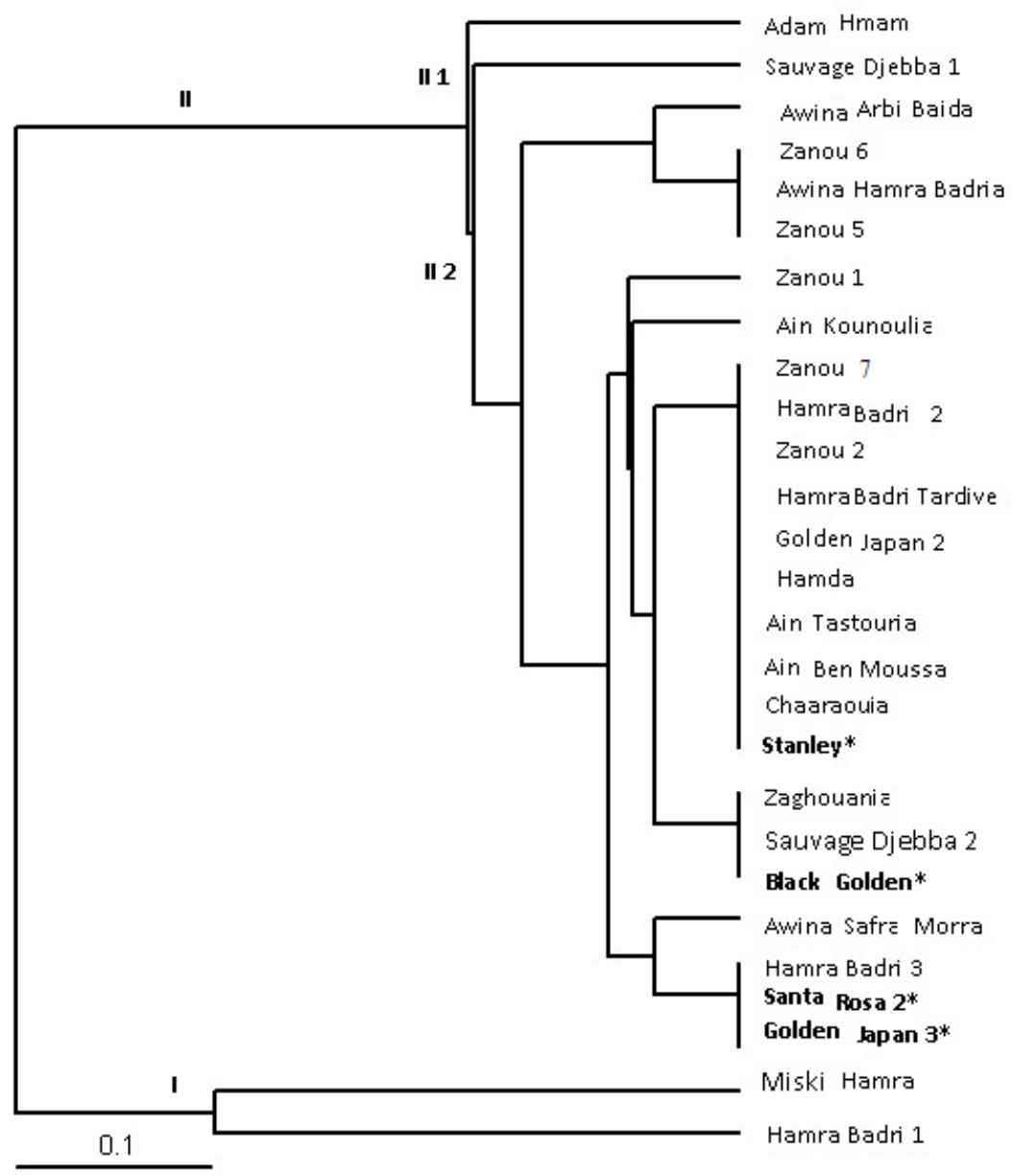

Figure 3. UPGMA dendrogram of 27 plum cultivars based on mitochondrial PCR-RFLP markers. Bold *introduced varieties. 


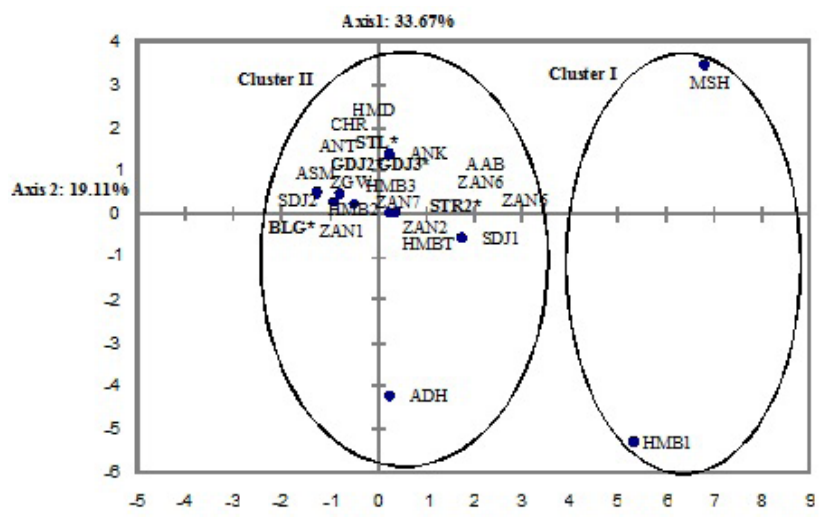

Figure 4. A Principal component analysis scatterplot of Tunisian plum cultivars based on mitochondrial DNA PCR-RFLP markers (52.78\% of the total variability explained). AHB: Awina Hamra Badria; CHR: Chaaraouia; ZAN5: Zanou 5; STL: Stanley; ABM: Ain Ben Moussa; AAB: Awina Arbi Baida; ANT: Ain Tastouria; ZAN6: Zanou 6; HMD: Hamda; MSH: Miski Hamra; SDJ1: Sauvage Djebba 1; SDJ2: Sauvage Djebba 2; STR2: Santa Rosa 2; GDJ2: Golden Japan 2; ASM: Awina Safra Morra; BLG: Black Golden; HMB1: Hamra Badri 1; GDJ3: Golden Japan 3; ANK: Ain Kounoulia; HMBT: Hamra Badri Tardive; ZAN1: Zanou 1; ZAN2: Zanou 2; ZGW: Zaghouania; HMB3: Hamra Badri 3; HMB2: Hamra Badri 2; ZAN7: Zanou 7; ADH: Adam Hmam.

\section{Minimum-length spanning tree analysis}

\section{Chloroplast DNA haplotypes}

The genetic relationships among the 17 cpDNA haplotypes are presented in Table 3 . The minimum length spanning tree offers a representation of linked haplotype groups based on the mutational differences among them. One cpDNA haplotype, H3, is shared by two accessions Jinha and Awina Hamra Badria and 16 haplotypes are unique to their respective accessions. The chlorotype $\mathrm{H} 2$ was ambiguously placed in the network and occupied a unique cluster in the UPGMA tree. This may reflect the high cpDNA diversity of this accession. Four putative haplotypes (mv) corresponding to intermediate evolutionary steps were not detected in our data set (Figure 5).

Table 3. Mitochondrial and chloroplast haplotypes detected in plum germplasms using PCR-RFLP markers.

\begin{tabular}{ll}
\hline Mitochondrial haplotypes & Chloroplast haplotypes \\
\hline H1: Awina Hamra Badria, Zanou 5, Zanou 6 & H1: Badri \\
H2: Chaaraouia, Stanley, Ain Ben Moussa, Ain Tastouria, Hamda, & H2: Awina Safra \\
Golden Japan 2, Hamra Bardi Tardive, Zanou 2, Zanou 7, Hamra Badri 2 & H3: Jinha, Awina Hamra Badria \\
H6: Awina Arbi Baida & H4: Ain Kounoulia \\
H10: Miski Hamra & H5: Cidre 1 \\
H11: Sauvage Djebba 1 & H6: Neb Zarouk \\
H12: Golden Japan 3, Santa Rosa 2, Hamra Badri 3 & H7: Hamda \\
H13: Sauvage Djebba 2, Black Golden, Zaghouania & H9: Golden Japan 1 \\
H15: Awina Safra Morra & H10: Ain Torkia \\
H17: Hamra Badri 1 & H11: Santa Rosa 1 \\
H19: Ain Kounoulia & H12: Zaghouania \\
H21: Zanou 1 & H13: Ain Tastouria \\
H27: Adam Hmam & H14: Miski Kahla 1 \\
& H15: Sauvage Raf-Raf \\
& H16: Hamra Badri 2 \\
& H17: Stanley \\
& H18: Chaaraouia \\
\hline
\end{tabular}




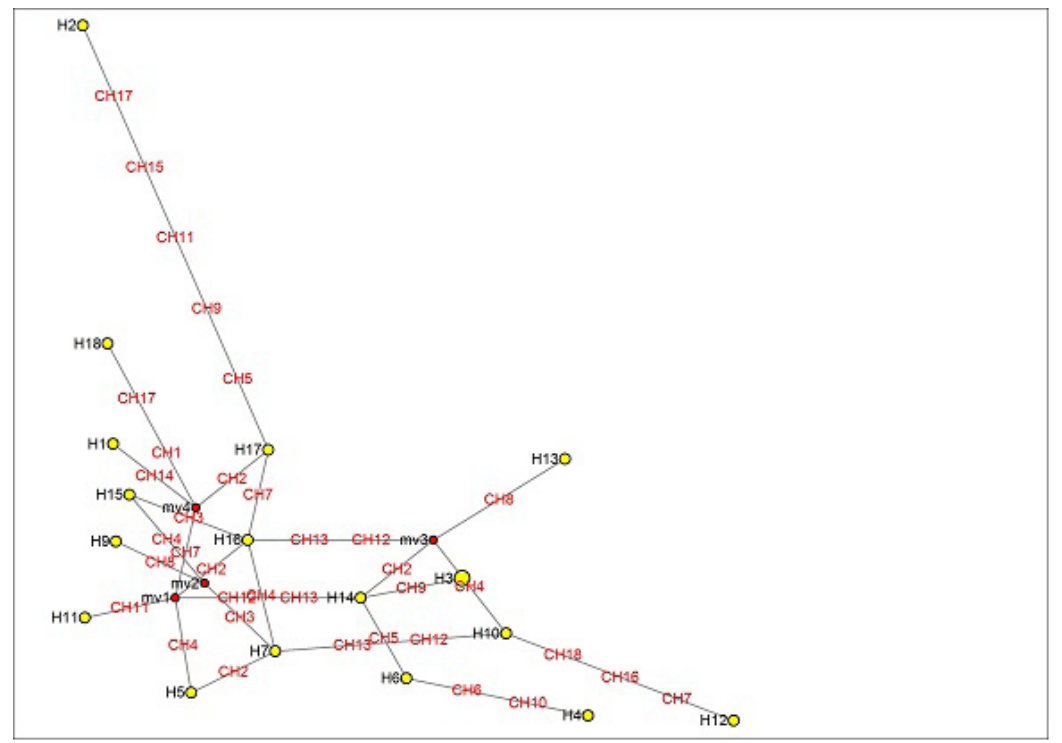

Figure 5. Minimum-length spanning tree of 17 chloroplast DNA haplotypes from the 18 plum cultivars studied.

\section{Mitochondrial DNA haplotypes}

The combination of all the identified mutations resulted in 12 mitotypes, which represent the 27 accessions studied (Table 3). Figure 6 shows the haplotypes detected using mitochondrial DNA. Haplotype H2 was present in 10 accessions: Chaaraouia, Stanley, Ain Ben Moussa, Ain Tastouria, Hamda, Golden Japan 2, Hamra Badri Tardive, Zanou 2, Hamra Badri 2, and Zanou 7. H1 was shared by 3 accessions: Awina Hamra Badria, Zanou 5, and Zanou 6. H13 was shared by Sauvage Djebba 2, Black Golden, and Zaghouania, and H12 was shared by Santa Rosa 2, Golden Japan 3, and Hamra Badri 3. All the other accessions were represented by unique haplotypes. It is important to note that all haplotypes are directly linked to the most frequent mitotype, $\mathrm{H} 2$, suggesting that this haplotype may be the ancestral mitotype (Figure 6).

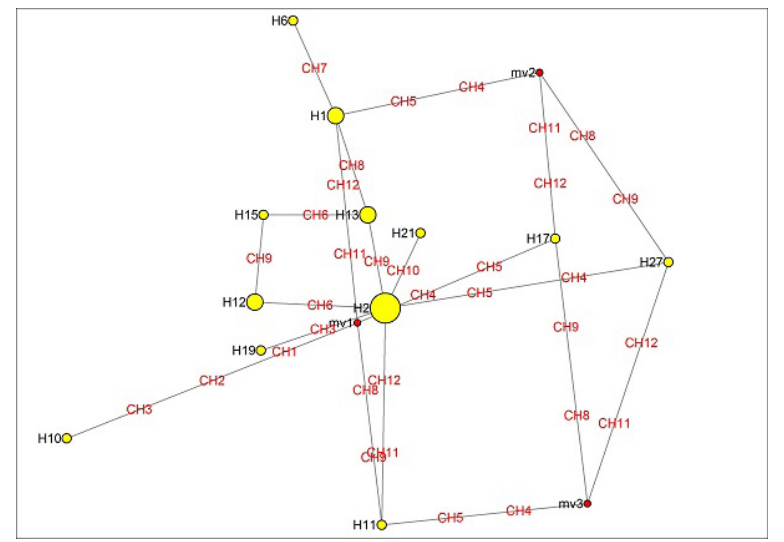

Figure 6. Minimum-length spanning tree of 12 mitochondrial DNA haplotypes from the 27 plum cultivars studied. 


\section{DISCUSSION}

In the current study, RFLP markers were used to estimate polymorphism and genetic diversity of Tunisian plum cultivars. Amplification of the $\operatorname{trn} \mathrm{L}-\mathrm{trn} \mathrm{F}$ region revealed a fragment of approximately $1000 \mathrm{bp}$, similar to results obtained for the genus Rosa (Bruneau et al., 2007), for Ficus carica (Baraket et al., 2010) and for Maloideae (Rosacea) (Verbylaitè et al., 2006). The mtDNA nad $1 \mathrm{~b} / \mathrm{c}$ intron was approximately $1500 \mathrm{bp}$ in length in this study, but has been found to vary in length among species, reaching up to 2100 bp (Demesure et al., 1995; Freudenstein and Chase, 2001; Sun, 2002; Mohanty et al., 2003). The nad 4 1/2 intron was approximately $2000 \mathrm{bp}$ in length, in agreement with the length reported for the nad 4 intron in other plant species (Dumolin-Lapègue et al., 1998; Pharmawati et al., 2012).

The PCR-RFLP technique was efficient in detecting cpDNA variation (17 polymorphic sites) in plum accessions compared with the 2 mtDNA regions (6 polymorphic sites). Seventy chlorotypes were detected for the 18 accessions studied. One haplotype was shared by two accessions and 16 were private. In contrast to the higher cpDNA diversity (17 haplotypes), the mtDNA showed lower levels of variation (only 12 haplotypes for the 27 accessions considered), which indicates the usefulness of chloroplast markers to detect polymorphisms. Our results are in agreement with those obtained for P. spinosa: 33 cpDNA haplotypes and two mtDNA haplotypes (Mohanty et al., 2003). Palmer (1992) and Mohanty et al. (2003) suggested that the low variation of mtDNA might be explained by the slow rate of nucleotide substitutions that occurs in mtDNA in comparison to cpDNA. It is likely that mtDNA evolves mainly in structure by intragenomic recombination via small repeated sequences dispersed within the genome (Palmer, 1992).

Of the 12 haplotypes observed in mtDNA, one was shared among 10 accessions. The haplotype $\mathrm{H} 2$ constitutes an internal node in the minimum spanning tree, probably reflecting its ancient origin, and may indicate a migrant pool model. Mitotypes H13 (Sauvage Djeba 2, Black Golden, and Zaghouania) and H12 (Santa Rosa 2, Golden Japan 3, and Hamra Badri 3) grouped plums belonging to P. salicina species represented by Golden Japan 3, the hybrid Santa Rosa, and Black Golden varieties, which suggests that the local cultivars Zaghouania and Hamra Badri 3 should be diploid and correspond to P. salicina species. However, this assumption must be confirmed by a cytogenetic study. The private haplotypes observed have special features and are very interesting for molecular characterization of plums. DumolinLapègue et al. (1998) suggested an older origin of cpDNA haplotypes in comparison with mtDNA haplotypes based on the distribution of cpDNA-mtDNA combinations. The relative age of the cpDNA-mtDNA haplotypes is one of the keys to understanding genome uncoupling. Failure in determining their relative age may result in difficulties in explaining the distribution and maintenance of genetic polymorphism in populations and species.

The UPGMA clusters showed that the distribution of cultivars was independent of their geographic origin, with similarities among local and introduced varieties. The traditional denominations are largely descriptive, therefore the correlation among the denominations and the molecular relationships derived from the cluster analysis are not surprising. The resolution of the marker system was sufficient to distinguish between plum cultivars, and to establish genetic relationships among the germplasm classes found. UPGMA cluster analysis did not show clear groupings based on geographic distance and exhibited unstructured variability in this crop. Thus, the cultivars tested in this study were characterized by large divergence at the DNA level, highlighting important genetic diversity among the genotypes sampled from Tu- 
nisia, which could be potentially incorporated into any further breeding programs and germplasm conservation.

The UPGMA tree and the PCA plot revealed congruent results, highlighting the association between local and introduced cultivars and their genetic proximity. This result is in congruence with previous results obtained for nuclear polymorphisms using RAPD markers in Tunisian plums by Ben Tamarzizt et al. (2009). In addition, trees belonging to the same variety, such as Hamra Badri 1, Hamra Badri 2, and Hamra Badri 3 show intra-varietal diversity based on this type of marker. To our knowledge, the present study is the first inventory aimed at characterizing the genetic diversity of plums using cytoplasmic markers. Our results on the polymorphism of cytoplasmic genomes clearly indicate a high level of diversity in the chloroplast genome and demonstrate the conservative nature of the mitochondrial genome and the slow rate at which mitochondrial organelle genomes evolve. The evolutionary changes in mtDNA are of a different nature from those in cpDNA. In fact, the concerted presence or absence of several restriction fragments is consistent with insertions or deletions.

In summary, the PCR-RFLP technique is a useful approach for identifying cytoplasmic variation among plum cultivars. The private haplotypes showed special features and need to be included when formulating guidelines for conservation and management of plum species.

\section{ACKNOWLEDGMENTS}

Research supported by grants from the Tunisian Ministère de l'Enseignement Supérieur et de la Recherche Scientifique.

\section{REFERENCES}

Bandelt HJ, Forster P and Rohl A (1999). Median-joining networks for inferring intraspecific phylogenies. Mol. Biol. Evol. 16: 37-48.

Baraket G, Ben Abdelkrim A, Saddoud O, Chatti K, et al. (2010). Molecular polymorphism of cytoplasmic DNA in Ficus carica L.: Insights from non-coding regions of chloroplast DNA. Sci. Hortic. 125: 512-517.

Ben Tamarzizt H, Baraket G, Ben Mustapha S, Marrakchi M, et al. (2009). Genetic relatedness among Tunisian plum cultivars by random amplified polymorphic DNA analysis and evaluation of phenotypic characters. Sci. Hortic. 121: 440-446

Bernatzky R and Tanksley SD (1986). Genetics of actin-related sequences in tomato. Theor. Appl. Genet. 72: 314-321.

Bouhadida M, Martín JP, Eremin G, Pinochet J, et al. (2007). Chloroplast DNA diversity in Prunus and its implication on genetic relationships. J. Am. Soc. Hort. Sci. 132: 670-679.

Bruneau A, Starr JR and Joly S (2007). Phylogenetic relationships in the genus Rosa: new evidence from chloroplast DNA sequences and an appraisal of current knowledge. Syst. Bot. 32: 366-378.

Demesure B, Sodzi N and Petit RJ (1995). A set of universal primers for amplification of polymorphic non-coding regions of mitochondrial and chloroplast DNA in plants. Mol. Ecol. 4: 129-131.

Dumolin-Lapègue S, Pemonge MH and Petit RJ (1998). Association between chloroplast and mitochondrial lineages in oaks. Mol. Biol. Evol. 15: 1321-1331.

Dutech C, Maggia L and Joly HI (2000). Chloroplast diversity in Vouacapoua americana (Caesalpiniaceae), a neotropical forest tree. Mol. Ecol. 9: 1427-1432.

Felsenstein J (1995). PHYLIP (Philogeny Interference Package) version 3.5c. Department of Genetics, University of Washington, Seattle.

Fineschi S, Taurchin D, Villani F and Vendramin GG (2000). Chloroplast DNA polymorphism reveals little geographical structure in Castanea sativa Mill. (Fagaceae) throughout southern European countries. Mol. Ecol. 9: 1495-1503.

Freudenstein JV and Chase MW (2001). Analysis of mitochondrial nadlb-c intron sequences in Orchidaceae: utility and coding of length-change characters. Syst. Bot. 26: 643-657.

$\mathrm{Hu}$ D and Luo Z (2006). Polymorphisms of amplified mitochondrial DNA non-coding regions in Diospyros spp. Sci. Hortic. 109: 275-281. 
Konieczny A and Ausubel FM (1993). A procedure for mapping Arabidopsis mutations using codominant ecotype-specific PCR based markers. Plant J. 4: 403-410.

Mohanty A, Martín JP and Aguinagalde I (2002). Population genetic analysis of European Prunus spinosa (Rosaceae) using chloroplast DNA markers. Am. J. Bot. 89: 1223-1228.

Mohanty A, Martín JP, Gonzalez LM and Aguinagalde I (2003). Association between chloroplast DNA and mitochondrial DNA haplotypes in Prunus spinosa L. (Rosaceae) populations across Europe. Ann. Bot. 92: 749-755.

Nei M and Li WH (1979). Mathematical model for studying genetic variation in terms of restriction endonuclease. Proc. Nat. Acad. Sci. U. S. A. 76: 5269-5273.

Okie WR and Weinberger JH (1996). Plums. In: Fruit breeding, Volume I: Tree and tropical fruits (Janick J and Moore JN, eds.). Wiley, New York, 559-607.

Palmer JD (1992). Mitochondrial DNA in plants systematics: applications and limitations. In: Molecular systematics of plants (Soltis PS, Soltis DE and Doyle JJ, eds.). Chapman and Hall, New York, 36-49.

Panda S, Martin JP and Aguinagalde I (2003). Chloroplast DNA study in sweet cherry cultivars (Prunus avium L.) using PCR-RFLP method. Genet. Resour. Crop Evol. 50: 489-495.

Pharmawati M, Yan G and Finnegan PM (2012). The conservation of mitochondrial genome sequence in Leucadendron (Proteaceae). Biodiversitas 13: 53-58.

Robertson A, Newton AC and Ennos RA (2004). Multiple hybrid origins, genetic diversity and population genetic structure of two endemic Sorbus taxa on the Isle of Arran, Scotland. Mol. Ecol. 13: 123-134.

Sun G (2002). Interspecific polymorphism at non-coding regions of chloroplast, mitochondrial DNA and rRNA IGS region in Elymus species. Hereditas 137: 119-124.

Taberlet P, Gielly L, Pautou G and Bouvet J (1991). Universal primers for amplification of three non-coding regions of chloroplast DNA. Plant Mol. Biol. 17: 1105-1109.

Verbylaite R, Ford-Lloyd B and Newbury J (2006). The phylogeny of woody Maloideae (Rosaceae) using chloroplast $\operatorname{trn} L-\operatorname{trn} F$ sequence data. Biologija 1: 60-63.

XLSTAT-Pro (2008). Statistical software for MS Excel (Version 7.0). Kovach Computing Services.

Wu J, Krutovskii KV and Strauss SH (1998). Abundant mitochondrial genome diversity, population differentiation and convergent evolution in Pines. Genetics 150: 1605-1614.

Yamagishi H and Terachi T (2003). Multiple origins of cultivated radishes as evidenced by a comparison of the structural variations in mitochondrial DNA of Raphanus. Genome 46: 89-94. 